\title{
HYPNOTICALLY ENHANCED TESTIMONY IN CRIMINAL PROCEEDINGS
}

\begin{abstract}
ALLAN DONOVAN*
The author discusses the use of hypnotically enhanced testimony in criminal proceedings. He outlines relevant American and Canadian case law to date. He points out weaknesses with this type of testimony and offers some possible safeguards, if hypnotism is to be used in our courts today.
\end{abstract}

\section{INTRODUCTION}

The debate over the admissibility of hypnotically enhanced testimony has raged in the United States for over two decades. The eighties have witnessed an explosion of American case law' and articles on the issue. Canada, on the other hand, is only now beginning to enter the fray.

In this paper I will examine the phenomenon of hypnosis and its use in refreshing the memory of witnesses in criminal proceedings. I will outline the hazards and limitations inherent in the technique and assess the various responses of the American judiciary to this new challenge. Finally I will examine the limited Canadian jurisprudence on the issue and suggest possibilities for law reform in the area.

\section{WHAT IS HYPNOSIS?}

Hypnosis, in the popular mind, has always been shrouded in a fog of mysticism. Indeed such an image is historically appropriate as hypnotism was employed by mystics and holy figures in many ancient civilizations. ${ }^{2}$ In essence, "soothsaying, magic, healing by laying on of hands, and various forms of witchcraft .. "3 were all manifestations of the hypnotic phenomenon.

Science has advanced. We would no longer be impressed by the suggestion of 18th century Viennese physician, Dr. Franz Anton Mesmer, that "Animal magnetism" flowed from the hypnotist's hands like an electric current over the patient. ${ }^{4}$ Through extensive research, hypnotism has developed into a recognized scientific technique found to be of substantial use in treating mental illness, pain, and amnesia. ${ }^{5}$

* Clerk to Madame Justice Wilson of the S.C.C., now completing his articles with the firm of McAlpine \& Hordo in Vancouver.

1. Infran. 91.

2. J.C. Jordan, "Admissibility of Hypnotically-Developed Evidence" (1984) 16 Ottawa L. Rev. 231 at 233.

3. Hovec, "Hypnotism Before Mesmer" (1975) 17 Am. J. Clinical Hypnosis 215; Ladd, “Legal Aspects of Hypnosis" (1902) 11 Yale L.J. 173.

4. Spector and Foster, "Admissibility of Hypnotic Statements: Is the Law of Evidence Susceptible?" (1979) 38 Ohio State L.J. 567 at 569.

5. Hypnosis has been recognized by both the American and British Medical Associations. 
Hypnosis has been defined by the British Medical Association and the American Medical Association as: ${ }^{6}$

... a temporary condition of altered attention in the subject which may be induced by another person and in which a variety of phenomena may appear spontaneously or in response to verbal or other stimuli. These phenomena include alternations in consciousness and memory, increased susceptibility to suggestion, and the production in the subject of responses and ideas unfamiliar to him in his usual state of mind.

An examination of this definition underlines the fact that scientific knowledge of hypnosis is largely limited to its observable outward characteristics. There is no consensus as to the physiological or psychological basis of hypnosis itself.'

The induction of a hypnotic trance is not a difficult task. A layman can become proficient in the mechanics of hypnosis with a few hours training. ${ }^{8}$ Typically the subject is asked to concentrate on a particular visual stimulus. After attention is properly focused, the subject will be asked to close his eyes, leaving the voice of the hypnotist as the sole external stimulus. ${ }^{9}$ It is estimated that between 90 and 95 percent of people are hypnotizable. ${ }^{10}$ The least likely candidates are individuals incapable of intense concentration: small children and flighty adults.

The literature divides hypnotic states into six distinct levels or depths, ${ }^{11}$ distinguishable by subjects' observable behaviour. The first and second stages, the "hypnoidal" stages, are characterized by total relaxation and an inability of the subject to open his eyes. The third and fourth stages, the medium trance, see the subject in a highly suggestible state, with concentration so deeply focused that he or she is often incapable of feeling pain. ${ }^{12}$ In the fifth and sixth stages, the deep trance, the subject loses his sense of touch and is capable of positive and negative hallucination at the suggestion of the hypnotist. ${ }^{13}$

It is undoubted that amazing feats have been achieved through hypnosis. Limbs have been amputated with only hypnosis used as an anesthetic. ${ }^{14}$ Subjects have been regressed in age to relive incidents in their life. ${ }^{15}$ Events that escaped the memory of individuals in a conscious state have been described in great detail under hypnosis. ${ }^{16}$ By the implanting of a posthypnotic suggestion these reconstructed events can be incorporated into

6. See E.K. Murray, "Admissibility of Present Recollection Restored by Hypnosis" (1979) 15 Wake Forest Law Rev. 357 at 359-360.

7. Spector, supra n. 4 at 569.

8. See W.S. Hibbard and R.W. Worring, Forensic Hypnosis The Practical Application of Hypnosis in Criminal Investigations (1981).

9. Id.

10. Spector, supra n. 4 at 575.

11. Id. at 571.

12. Id. at 572 .

13. Id.

14. Id. at 567.

15. M. Orne, "The Mechanisms of Hypnotic Age Repression" (1951) 46 J. Abnormal and Soc. Psych. 213.

16. Id. 
the conscious memory of the subject. ${ }^{17}$ It is around this latter use of hypnosis that the debate in the criminal law field has been focused.

\section{HYPNOTICALLY ENHANCED TESTIMONY}

\section{A. THE BENEFITS}

Criminal charges often arise from incidents involving violence, shock or degradation. Further, it is not infrequent that either the accused, the victim, or a witness had partaken of alcohol or drugs at the time of the alleged criminal act. Therefore, memories are often foggy and the temptation exists to restore them through hypnosis.

Law enforcement agencies have used hypnosis as an investigatory tool for quite some time. Its primary use is producing information which in turn is used to acquire independent confirmatory evidence. ${ }^{18}$ There have been a number of spectacular success stories, such as the California case where police hypnosis of a bus driver produced all but one digit of a license plate number of a van used in kidnapping 26 school children. ${ }^{19}$ There are over 1,000 American police officers who are trained in hypnosis. ${ }^{20}$ Indeed, a whole cottage industry seems to be springing up around the training of police officers as "hypno-investigators".21

It has been strenuously argued that the role of hypnosis should extend beyond the investigatory stage to the actual trial process. ${ }^{22}$ As one writer notes: ${ }^{23}$

The accumulation of data from studies ... makes it safe to conclude that hypnotic recall generally contains more facts than are available in the waking state and that these facts are no less valid than those produced during conscious remembering.

Thus, it is suggested by some writers that hypnosis is just another memory aiding device. Therefore, just as a police officer may refresh his/her memory from his/her professional notes, so should a witness be allowed to refresh his/her memory by the use of hypnosis. ${ }^{24}$ The validity of this analogy will be examined below, when we assess the reliability of hypnotic enhancement of memory.

While it is usually the prosecution that desires the introduction of hypnotically enhanced evidence, this is not always the case. In Greenfield v. Commonwealth, ${ }^{25}$ the accused was charged with murder. While under the influence of a hallucinogen and heroin the accused went for a drive with

17. B. Diamond, "Inherent Problems in the Use of Pretrial Hypnosis on a Prospective Witness" (1980) 68 Cal. L.R. 313 at 332-335.

18. L. Haward and A. Ashworth, "Some Problems of Evidence Obtained by Hypnosis" [1980] Crim. L.R. 469 at 472.

19. Spector, supra n. 4 at 580 .

20. M.D. Kirby, "Hypnosis and the Law" (1983-84) 8 Crim. L.J. 152 at 153.

21. Id. at 157.

22. See Spector, supra n. 4.

23. Haward, supra n. 18 at 475.

24. Spector, supra n. 4 at 585.

25. 314 Va. 710, 204 S.E. 2d 414 (1974); Greenfield v. Robinson 413 F. Supp. 1113 (W.D. Va. 1976). 
the victim. The accused claimed that he blacked out and that he awoke to see the victim knifed to death beside him, and someone running from the car. The defence sought to introduce psychiatric evidence based on the hypnosis of the accused, to establish that the accused had lost consciousness while in the car. This evidence was excluded and Mr. Greenfield was convicted. ${ }^{26}$ Clearly the issue of reliability of hypnotically enhanced evidence must be examined in order to determine the validity of both defence and prosecution strategies.

\section{B. THE HAZARDS}

\section{Suggestibility}

Hypnosis is a state of dramatically increased suggestibility. ${ }^{27}$ As the subject generally wishes to please the hypnotist, he responds to even the most remote cues. ${ }^{28}$ As Spector points out: ${ }^{29}$

The very suggestibility of the subject, which permits induction into hypnosis, also provides interpretive difficulties. The hypnotized subject may respond to implicit stimuli unintentionally emanating from the hypnotist, and unrecognized by him.

This problem is exacerbated by the fact that these suggestions are often translated into "pseudomemories" that last after the hypnosis is over..$^{30}$ Thus the potential exists for the intentional or inadvertent implanting of false memories in the subject, and a resultant "vicarious perjury." 31

This issue has been addressed by a leading critic of hypnotically enhanced testimony, Dr. Bernard L. Diamond. Dr. Diamond argues that the problem is so acute that "once a potential witness has been hypnotized for the purpose of enhancing memory his recollections have been so contaminated that he is rendered effectively incompetent to testify". ${ }^{32}$ It becomes impossible for either the subject or the trier of fact to distinguish true memories from those created by suggestion.

Suggestibility is not a mere academic difficulty. Several recent American cases underline the grave dangers inherent in this phenomenon. In one recent case from North Carolina, ${ }^{33}$ a young black man named Reece Forney was charged, along with three other black men, with the rape and murder of an elderly white woman. There were neither witnesses nor physical evidence connecting the four to the scene of the crime. The case was largely based on the hypnotically enhanced testimony of Mr. Forney.

At trial the prosecution emphasized the fact that Forney had mentioned seeing a rake at the scene of the crime. As no press reports had mentioned a rake, it was argued that Forney must have been present since he knew of its existence. A reading of the text of Forney's hypnotic experience, however,

26. See discussion in Spector, supra n. 4, at 611 .

27. K.Z. Pelanda, "The Probative Value of Testimony from the Hypnotically Refreshed Recollection" (1980-81) 14 Akron L. Rev. 609 at 622.

28. Diamond, supra n. 17 at 333.

29. Spector, supra n. 4 at 578.

30. Diamond, supra n. 17.

31. Haward, supra n. 18 at 471.

32. Diamond, supra n. 17 at 314.

33. See account in Kirby, supra n. 20 at 159. 
renders this contention somewhat problematic: ${ }^{34}$

Forney: (describing walking home after the crime). Seems like I grabbed something and ran back to - I walked most of the way because I was so tired.

Hypnotist: (handed a note by a policeman, which instructed him to ask about a rake).

What did you grab?

Forney: Base of something - base of something.

Hypnotist: Was it a rake?

Forney: I don't know. It could have been.

Hypnotist: Where did you get the rake from?

Forney: I think I got it from the yard of the house, I was so mad, Lester run back (inaudible), run back.

Hypnotist: What are you doing with the rake?

Forney: Runing down at them - seems like I was fighting them.

Hypnotist: Did they take the rake from you?

Forney: Yeah.

Despite the overtly suggestive questioning by the hypnotist the evidence elicited founded a conviction of the four men.

This case does not stand alone. State v. Hurd ${ }^{35}$ involved a serious stabbing of a woman while she lay sleeping. The two suspects were the woman's current husband and her former husband. The woman was hypnotized and asked to "relive" the event. She identified her former husband, Mr. Hurd, as her assailant. Her current husband, however, was allowed to be present during the hypnotic interview. His very presence, the Court decided, could have prevented the victim from viewing him as a suspect. ${ }^{36}$

A final example can be found in the case of People v. Davis. ${ }^{37}$ Here a witness underwent pre-trial hypnosis to enhance her memory concerning a violent robbery. The following exchange occurred during a session that a police-hypnotist testified was free from suggestion: $:^{38}$

Hypnotist: Now Connie, I'm going to count to three . . . and when I do, these two people who were wearing masks, you'll be looking at them ... One, two, three. That's fine. How many of them are there?

Subject: Two.

Clearly the heightened suggestibility inherent in the hypnotized subject is a source of serious concern.

Some writers have attempted to downplay the dangers of suggestibility by noting that regular eyewitness testimony is subject to the same frailty. Spector notes that: ${ }^{39}$

Once verbalization occurs, it may displace original sense impressions and memory, so that the witness subsequently bases his responses on the oral account, convinced that it originated from his own observations. It has been demonstrated, for example, that varying even one word in a single question can, dramatically and systematically, alter the initial account of an occurrence.

34. J. Bélanger, et al, "L'hypnose psycho-légale: Une histoire à suivre" (1984) 44 Rev. du Bar. 869 at 886-887.

35. 173 N.J. Super. 333, 414 A. 2 d 291 (1980).

36. S. Berger, "Evidentiary Problems in the Use of Pre-Trial Hypnosis" (1985) 42 C.R. (3d) 63 at 66.

37. Cited in Pelanda, supra n. 27 at 626.

38. Id.

39. Spector, supra n. 4 at 592. 
While few would question Spector's premise that admissible eyewitness testimony is often tainted by distortion and suggestion, ${ }^{40}$ Spector's conclusion that hypnotically enhanced evidence should also be admissible does not follow. It is common ground among the writers, including Spector, that the problem of suggestibility is substantially heightened by the hypnosis process. ${ }^{41}$ Therefore, clearly the appropriate question is whether the probative value of this sort of evidence still outweighs its potential prejudicial effect. ${ }^{42}$

\section{Deceit and Confabulation}

While some early enthusiasts for the use of hypnosis in the criminal justice system felt that the process essentially guaranteed truth, ${ }^{43}$ the overwhelming consensus now is that lying while under hypnosis is possible. ${ }^{44}$ Thus hypnosis has no value as a lie detector and any value it does have flows from its ability to enhance the accuracy and detail of memory.

As noted above, the efficacy of hypnotically enhanced recall is limited by the subject's heightened suggestibility. It is also limited by the related problem of confabulation. Dr. Diamond describes this phenomenon as follows: ${ }^{45}$

Out of a desire to comply with the hypnotist's suggestions, the subject will commonly fill in missing details by fantasy or confabulation. Often these details are portions of other real memories, but ones unrelated to the situation that the hypnosis seeks to probe. Thus, the hypnotically recalled memory is apt to be a mosaic of (1) appropriate actual events, (2) entirely irrelevant actual events, (3) pure fantasy, and (4) fantasized details supplied to make a logical whole.

Thus, the accuracy enhancing ability of hypnosis may be more apparent than real.

A number of studies confirm this thesis. One study, noting the incredible detail achieved under age regression hypnosis, attempted age "progression" under hypnosis. This study found that the same sort of detail was given of future events and surroundings as was given for past events. ${ }^{46}$ This study underlined the problem that hypnotically enhanced memories lie somewhere in the twilight zone between fact and fantasy.

Of equal interest is a recent study by Dylvan and Bowers. ${ }^{47}$ This experiment involved comparing the capacity for memorization between hypnotized and non-hypnotized subjects. The study revealed that the deeply hypnotized group produced twice the number of correct answers than the control group produced. At the same time, however, this group

40. E. Loftus and C. Wells, (Eds.) Advances in the Psychology of Eye-Witness Testimony (1984).

41. Spector, supra n. 4 at 593.

42. See discussion infra at notes 133-135.

43. See W. Bryan, Legal Aspects of Hypnosis (1962).

44. J.A. McLaughlin, "Hypnosis - Its Role and Current Admissibility in the Criminal Law" (1980-81) 17 Will. Law. Rev. 665 at 670; Spector, supra n. 4 at 577.

45. Diamond, supra n. 17 at 335.

46. Rubenstein, "The Living Out of 'Future' Experiences Under Hypnosis" (1954) 119 Science 472.

47. J. Dywan and K. Bowers, "The Use of Hypnosis to Enhance Recall" (1983) 222 Science 184. 
produced three times the number of errors. ${ }^{48}$ Thus, in a paradoxical way, hypnosis both increases and decreases accuracy of recall. This point may pose substantial difficulties for the trier of fact, given that no scientific means exists for separating the wheat from the chaff..$^{49}$

This problem of confabulation may well be exacerbated by standard techniques employed in promoting hypnotic recall. One typical approach involves the hypnotist suggesting that the subject imagine himself watching his favorite TV program: ${ }^{\text {so }}$
After the hallucinatory program ends, the witness is told a documentary will follow and that it will depict the events of the crime as the witness saw them. The event is then recreated by using such film techniques as slow motion, freeze frame, and instant replay. Where descriptions were fuzzy in the original testimony, the camera zooms in on the scene, enabling the witness to recall details of his or her "flash experience".

In the opinion of many experts, this sort of approach amounts to an invitation to confabulate..$^{51}$ The simple fact is that the original scene may never have been perceived with movie camera clarity. It was certainly not perceived with a zoom lens. By suggesting otherwise to the subject the hypnotist moves the resulting story one step further from reality. ${ }^{32}$

Another dangerous and unrealistic suggestion often employed by hypnotists is found in Hibbard's handbook on the training of police in hypnosis. Here it is stated that the following suggestion should be made to a subject who is having difficulty remembering particular facts: ${ }^{53}$

Now I am going to talk to your subconscious mind. We know that everything we experience is recorded in our subconscious, but that most is unavailable consciously. If you truly saw the license number ... your subconscious mind will be able to give your conscious mind that information, and it will do so when I count up to three.

Modern theories of memory do not confirm the belief that everything perceived is stored somewhere in the brain and that the only problem is access. ${ }^{54}$ By suggesting that this is the case, the hypnotist gives permission to the subject to create pseudomemories.

The case of People v. Kempinski ss illustrates the danger posed by confabulation in a criminal law context. In this case the accused was charged with murder. He was identified by an eyewitness whose memory had been hypnotically enhanced. The identification was made at a distance of 270 feet in the twilight. At trial, expert evidence established that the visibility under these light conditions was only twenty-five feet. The identification, therefore, was based on an enhanced imagination rather than a revived memory. It is clear that the potential for inadvertent confabulation is a serious drawback inherent in hypnotically refreshed testimony.

48. See Bélanger, supra n. 34 at 881.

49. Diamond, supra n. 17 at 340.

50. McLaughlin, supra n. 44 at 669.

51. Diamond, supra n. 17 at 340; Berger, supra n. 36 at 669; Bélanger supra n. 34 at 889.

52. Bélanger, Id.

53. Hibbard, supra n. 8 at 178.

54. E.F. Loftus and G.R. Loftus, "On the Permanence of Stored Information in the Human Brain" (1980) 35 American Psychologist, 409.

55. Unreported, no. W80CF 352 Cir. Ct. 12th Dist., Will. Co., Ill., October 21, 1980. 


\section{Undue Weight}

Numerous writers have expressed the fear that juries might give undue weight to hypnotically enhanced evidence. ${ }^{56}$ It is clear that any jury that assumed that hypnosis guaranteed accuracy or truth would give this sort of evidence excessive weight. The problem, however, goes deeper than this.

Hypnosis seems to have a remarkable ability to resolve doubts in the mind of the subject. Studies have indicated that even where hypnosis has not objectively enhanced recall, it does succeed in increasing the subject's confidence in his story. ${ }^{57} \mathrm{By}$ this process, therefore, testimony is hardened, and the typical indicia of doubt, such as confusion or hesitation, are removed..$^{38}$ Thus hypnosis, by its impact on the demeanor of the witness, may increase his credibility, independent of any enhancing of his memory.

\section{Lack of Effective Right to Cross-Examination}

A related problem of hypnotic enhancing of testimony is that the process may tend to leave subjects virtually impervious to cross-examination. ${ }^{39}$

A witness who has confabulated under hypnosis does not know that his testimony is false; he actually believes it to be true. This belief . . . neutralizes any effect that the oath or a penalty for perjury might have on the witness. . . . The witness cannot be made to admit the falsity of his pseudo-memories because he is absolutely convinced of their veracity. 60

The confidence that the witness has in his story will limit the effectiveness of cross-examination as a tool for undermining the opposing case.

\section{SAFEGUARDS}

In order to assess the true gravity of the hazard of hypnotically enhanced testimony, we must assess the degree to which procedural safeguards can eliminate them. We now turn, therefore, to six suggested safeguards, and speculate on their potential value.

\section{Recording the Hypnosis Sessions}

Most writers agree that if hypnosis is to be employed, the sessions should be videotaped..$^{60}$ The keeping of an accurate record of the sessions would allow the opposing party to search for improper suggestions or leading questions utilized by the hypnotist. A mere written transcript of the session would not suffice, and could "be misleading as it may not adequately convey the communication of cues and suggestions by the hypnotist through tone of voice and 'body language' to his subject."61

While videotaping is clearly a valuable safeguard, it can only control against suggestions made during the hypnotic session. It has been noted,

56. C.V. Morley, "State v. Martin - The Admissibility of Hypnotically Refreshed Memory" (1985) 21 Will. L.R. 186 at 191; Diamond, supra n. 17 at 339; Jordan, supra n. 2 at 253.

57. Bélanger, supra n. 34 at 881.

58. Diamond, supra n. 17 at 339.

59. M.A. Christensen, "Pretrial Hypnosis and its Effect on Witness Competency in Criminal Trials" (1983) 62 Neb. L.R. 336 at 350; R. Udolf, Forensic Hypnosis (1983) 82.

60. Christensen, Id. at 345; McLaughlin, supra n. 44 at 685.

61. Jordan, supra n. 2 at 257. 
however, that suggestions made prior to hypnosis can influence the outcome of the hypnotic session. ${ }^{62}$ This point is clearly illustrated by State v. Mack..$^{63}$ In this case a woman had, while inebriated, engaged in sex with a man she had met in a bar. She later found herself bleeding, and revealed under hypnosis that Mr. Mack had knifed her repeatedly in the vagina. Medical evidence established that the victim was not knifed, and that her bleeding was explicable by her gynecological history. It has been argued that the knifing story was a confabulation based on pre-hypnotic suggestion made by an intern in the emergency room..$^{64}$

Another example of the danger posed by extra-hypnotic suggestion is found in the case of Emmett v. Ricketts. ${ }^{64 A}$ The prosecution's case in this murder trial rested almost entirely on the testimony of one witness, Deborah Kidd. While the psychologist testified that there had been no improper suggestions communicated, it turned out that Ms. Kidd had been instructed to read the newspapers and cut out anything relevant to the crime. ${ }^{65}$ This sort of case makes it clear that the problem of suggestibility will not be totally corrected by videotaping.

\section{Neutral Setting}

As the physical surroundings have been known to affect the results of hypnosis, it is desirable that the surroundings be as neutral as possible. ${ }^{66}$ Frequently, however, the setting is not neutral. This problem is underlined by an excerpt.from Hibbard's manual on how to make the subject feel comfortable prior to hypnosis. Here he states: ${ }^{67}$

... keeping in mind the powerful connotations and feelings some people have about law enforcement authorities and police stations, ask the subject if he would like a tour .... Introduce the subject to some department personnel.

The problem, of course, is that the atmosphere of the police station itself is highly suggestive. The witness is given subconscious cues as to his role; convicting the accused. ${ }^{68}$

\section{Qualified and Neutral Hypnotist}

It is clear from the discussion above that the hypnotic enhancing of evidence in a criminal proceeding is a delicate and important task. As the liberty of the accused hangs in the balance, any error made may have grave consequences. Clearly the hypnotist's competence is of paramount importance. As Jordan points out: ${ }^{69}$

The myriad of methods by which a hypnotist may, either intentionally or unintentionally suggest a response to the subject would seem to indicate that a high degree of training and experience is required for the task.

62. Diamond, supra n. 17 at 339.

63. Minn. 292 N.W. $2 d 764$ (1980).

64. Bélanger, supra $\mathrm{n} .34$ at 883.

64A. 397 F. Supp. 1025 (N.D. Ga. 1975).

65. Diamond, supra n. 17 at 325.

66. N.J. Dilloff, "The Admissibility of Hypnotically Influenced Testimony" (1977) 4 Ohio N.U.L.R. 1 at 4.

67. Hibbard, supra n. 8 at 84.

68. Dilloff, supra n. 66 at 19; Pelanda, supra n. 27 at 629; McLaughlin, supra n. 44 at 672.

69. Jordan, supra $\mathrm{n} .2$ at 255. 
Some debate exists, however, over what constitutes a qualified hypnotist.

Some cases have involved hypnotists whose objectivity and qualifications were dubious in the extreme. In both People v. Tait ${ }^{70}$ and United States v. Miller," the hypnotist had a fair stake in the proceeding; he was the prosecuting attorney! In State v. Palmer 2 the hypnotist's formal training consisted of a four day course on hypnosis and limited practice, mainly on classmates. There is a general consensus that this sort of situation cannot be tolerated. ${ }^{\text {p }}$

Hibbard and various other writers of "how-to" manuals, feel that a police officer can be given the necessary expertise in the area by a brief training course. ${ }^{74}$ Many writers, however, disagree, and point out that while police hypnotists are in general technically competent, they lack a sophisticated appreciation of the psychological and scientific nature and limitations of hypnosis. ${ }^{75}$ Thus, the better view seems to be that the hypnotist should be a psychologist or psychiatrist with formal training in hypnosis.

This position against the use of police hypnotists is bolstered by considerations of hypnotist neutrality. Mental health professionals, states Dr. Martin Orne::76

\begin{abstract}
... are less likely to have information or preconceptions about details of the case, and to the extent that they lack information, they are not in a position to bias, unduly influence, or contaminate the hypnotized individual's recollections. The empirical evidence would suggest that if hypnosis is to be used in an attempt to "refresh" memory, it should be administered by an expert who has minimal preconceptions about the to-be-remembered event and little investment in the ultimate disposition of the case.
\end{abstract}

The police have a theory as to the way events occurred, they know a number of details about the crime and they have a vested interest in solving the case. Considerations of neutrality would seem to call for a professional hypnotist, working in a professional environment.

\title{
4. No Hypnosis in Courtroom
}

A few cases involving hypnotic enhancing of evidence have gone so far as to allow the hypnosis to be conducted in the courtroom. ${ }^{7}$ Even those commentators most favourable to the use of hypnosis are opposed to this development. ${ }^{78}$ In-court refreshing of memory through hypnosis is no more effective than the same process out of court. The only difference is that the former is more theatrical. The prevention of the use of courtrooms as a stage for memory enhancing hypnosis will serve as a partial answer to the "undue weight" criticism.

70. 99 Mich. App. 19, 297 N.W. (2d) 853 (Ct. App. 1980).

71. 411 F. 2d 825 (2d Cir. 1969); 296F. Supp. 422 (D.C. Conn. 1968).

72. 210 Neb 206,313 N.W. 2 d 648 (1981).

73. Udolf, supra n. $\mathbf{5 9}$ at 90.

74. Hibbard, supra n. 8.

75. Pelanda, supra n. 27 at 625 ; Jordan, supra n. 2 at 256.

76. M. Orne, et al. "Hypnotically-induced Testimony and the Criminal Justice System" in Loftus, supra n. 40.

77. E.g. R. v. Pitt [1968] 3 C.C.C. 342.

78. Spector, supra n. 4 at 596; Jordan, supra n. 2 at 262. 


\section{Expert Evidence}

Dilloff sees expert evidence concerning the limits and dangers of hypnotically enhanced testimony as the "primary antidote for possible deception of the trier of fact". ${ }^{79}$ Indeed, it seems clear that the examination and cross-examination of a hypnosis expert could help to establish both the strengths and the frailties of the process.

It has been noted, however, that hypnosis experts called in criminal trials are often willing to testify that the enhanced memory is in his opinion truthful and accurate. ${ }^{80}$ As discussed above, it is beyond the competence of any hypnotist, no matter how skilled, to make such claims. ${ }^{81}$ Dr. Diamond suggests that these hyperbolic claims stem from the ignorance of the "experts" of the scientific research concerning the shortcomings of hypnosis in a legal context. ${ }^{82}$ Thus, if expert testimony is to be a safeguard in these proceedings, opposing counsel should be ready with his own professionally trained expert to dispute any inaccuracies arising.

\section{Caution to the Jury}

If hypnotically enhanced testimony is to be admitted, the jury should be fully warned as to its limitations. As one writer puts it, "[a]fter a "battle of the experts', the jury needs an impartial instruction detailing the judicial attitude toward and the scientific data on hypnosis."

There is a general agreement that the charge to the jury should emphasize the following facts:

(a) Hypnosis does not guarantee truth; its function is to act as a memory aid, not as a lie detector; ${ }^{84}$

(b) Hypnotically enhanced testimony is subject to all of the frailties of regular eyewitness testimony; ${ }^{85}$ and

(c) The reliability of hypnotically enhanced testimony is impaired by problems peculiar to hypnosis; confabulation and heightened suggestibility. ${ }^{86}$

There can be no doubt that a jury so instructed would be less likely to give undue weight to this sort of evidence.

This is not to say, however, that the jury's task would be an easy one. A properly instructed jury would know that a certain portion of hypnotically enhanced memory may well be mere fantasy. They would also know that they have no basis on which to distinguish the fact from the fantasy. The jury would then be asked to decide factual disputes in this alien territory without the aid of traditional measures of credibility. The results could well be arbitrary. ${ }^{87}$

79. Dilloff, supra n. 66 at 9.

80. Diamond, supra n. 17 at 341; McLaughlin, supra n. 44 at 621.

81. See text corresponding to notes 43-55.

82. Diamond, supra n. 17 at 341.

83. McLaughlin, supra n. 44 at 688.

84. McLaughlin, id.; Jordan, supra n. 2 at 258.

85. Jordan, id.

86. Id.; Pelanda, supra n. 27 at 630.

87. Pelanda, id. 


\section{Cumulative Impact}

If the safeguards listed above were to be implemented, there is no doubt that the reliability of hypnotically enhanced evidence would be increased. It should be noted, however, that none of these safeguards address the problem of confabulation and the related problem of unwarranted certainty under cross-examination. These "subject based dangers" are an intrinsic part of the hypnosis package. No method exists to correct for them. ${ }^{88}$

\section{THE AMERICAN CASE LAW}

The first reported case on the use of hypnosis in a criminal case is People v. Ebanks. ${ }^{89}$ Here the Court simply decided that "the law of the United States does not recognize hypnotism."90 Very few cases involved hypnotically enhanced evidence until the early 1970 's. Since then these cases have increased geometrically. Indeed the United States is in the midst of a miniexplosion in this area; more cases involving hypnotically enhanced testimony have appeared since 1980 than appeared in all the years previous. ${ }^{91}$ Four basic approaches can be culled from the mass of recent American cases, and these approaches will now be examined.

\section{A. THE ADMISSIBILITY APPROACH}

The landmark case for the admissibility approach is the Court of Special Appeals of Maryland's decision in Harding v. State. ${ }^{\text {2 }}$ Here the victim was shot and then raped. She suffered from partial amnesia and her memory of the incident was "restored" through the use of hypnosis. By post-hypnotic suggestion, the victim was able to testify about previously unremembered details of the crime in a normal waking state. Largely on the basis of this testimony, Mr. Harding was convicted. The critical issue, both at trial and on appeal was the admissibility of hypnotically enhanced testimony.

At all three levels, the Maryland courts found the testimony admissible. The decisions were based on first principles of evidence. It is the role of the trier of fact to assess the weight to be given to evidence and the credibility of witnesses, stated the Court..$^{93}$ Hence, hypnotically enhanced evidence was seen as admissible, leaving it to the jury to assign this evidence the appropriate weight. No direction was given to the jury as to what the appropriate weight was, other than the instruction that no more weight should be given to this sort of testimony than is given to any other testimony.4

88. Id. at 629 .

89. 117 Cal. 652,49 P. 1049 (1897).

90. Id. at 656,49 P. at 1053 .

91. Note, "State v. Collins" (1984) 43 Maryland L.R. 595 at 600.

92. 5 Md. App. 230, 246A. 2d 302 (1968), cert. denied, 395 U.S. 949 (1969).

93. Id. at 236, 246A $2 \mathrm{~d}$ at 306.

94. Id. at 244, 246A. 2 d at 310. 
The Harding decision has been harshly criticized by some commentators. Dilloff notes that the setting for the hypnosis was far from neutral.95 The hypnosis was conducted in police barracks and the victim was questioned by a state trooper after coming out of hypnosis. Further, he points out, since the expert witness who testified at trial was the hypnotist who hypnotized the victim, "he had a vested interest in vouching for his own procedures and their reliability."\%

Indeed the expert in Harding was somewhat over-enthusiastic in his assessment of the merits of hypnotism. He testified that the hypnotised subject does not suffer from heightened suggestibility. ${ }^{97}$ Dr. Diamond suggests that: ${ }^{98}$

$\ldots$ if the Harding trial and the appellate courts had been presented a more accurate description of the nature of hypnosis and the extreme vulnerability of the subject to suggestion, they might have been less disposed to admit the evidence, and the subsequent trend of the law might have been different.

Despite its weaknesses, however, Harding is precedent for the principle of per se admissibility of hypnotically enhanced evidence.

Throughout the seventies, a large body of case law developed based on the principle laid down in Harding. ${ }^{99}$ Some of these cases represented an alarmingly dogmatic tendency: suggesting in a facile way that everything went to weight, without examining the dangers inherent in hypnosis. By the early eighties most commentators concluded that per se admissibility was the general rule in the United States..$^{100}$ Already, however, new approaches had begun to break through the cracks in the surface of the old.

\section{B. THE SAFEGUARDS APPROACH}

The New Jersey case of Hurd v. State ${ }^{101}$ marked the start of a retreat from the Harding position. Here the Court concluded that unless certain safeguards were employed, hypnotically enhanced evidence could be extremely unreliable. ${ }^{102}$ If the safeguards had not been adhered to, the Court stated, the probative value of the evidence would be outweighed by the risk associated with it being admitted..$^{103}$ Therefore, unless the State established that the safeguards had been complied with, the hypnotically enhanced evidence would be excluded.

The safeguards laid down by Hurd are those suggested by Dr. Martin

95. Dilloff, supra n. 66 at 19.

96. Id. at 20.

97. Diamond, supra n. 17 at 322.

98. Id. at 323.

99. State v. McQueen 295 N.C. 96, 244 S.E. $2 d 414$ (1978); United States v. Awkard 597 F. $2 d 667$ (9th Cir. 1979), cert. denied, 444 U.S. 885 (1979); United States v. Narsico 446 F. Supp. 252 (E.D. Mich. 1977); Clark v. State 379 So. 2 d 372 (Fla. Dist. C. App. 1979); Creamer v. State 232 Ga. 137, 205 S.E. 2d 240 (1974); Chapman v. State 638 P. 2d 1280 (Wyo. 1982); State v. Jorgensen 8 Or. App. 1, 492 P. 2d. 312 (Ct. App. 1971); People v. Smrekar 68 IIl. App. 3d 379, 385 N.E. 2d 848, 24 III. Dec. 707 (App. Ct. 1977).

100. Murray, supra n. 6 at 369.

101. 86 N.J. 525,432 A. $2 \mathrm{~d} 86$ (1981).

102. Id. at $538-540,432$ A. $2 \mathrm{~d}$ at $92-94$.

103. Udolf, supra n. 59 at 85 . 
Orne for the conduct of a forensic hypnosis session. They may be summarized as follows: ${ }^{104}$

1. The session must be conducted by an experienced psychiatrist or psychologist;

2. The hypnotist must be independent of both the prosecution and the defence;

3. All information given to the hypnotist by prosecution, police or defence must be recorded;

4. The hypnotist must obtain a statement of facts from the subject prior to hypnosis;

5. All discussion between the hypnotist and subject must be recorded; and

6. No one other than the hypnotist and the subject may be present during the session.

These safeguards have been adopted by several courts since the Hurd decision. ${ }^{105}$

While adopted by many courts, the safeguards approach has not always been taken seriously. In People v. McDowell ${ }^{106}$ for instance, the Court laid down nine procedural safeguards seen as necessary to produce reliability. Seven of these nine safeguards were violated. The hypnotically enhanced evidence, however, was still admitted. Clearly, if the safeguards approach is to amount to anything more than a pious charade, it must be backed up by the sanction of exclusion.

The safeguards approach as enunciated in Hurd would seem to be an improvement over per se admissibility. Evidential unreliability flowing from poorly executed hypnosis and improper suggestion will be substantially reduced. As detailed earlier, however, these safeguards are powerless to deal with the subject-based dangers inherent in the hypnotic process. ${ }^{107}$

\section{THE EXCLUSION APPROACH}

Many jurisdictions in the United States have gone a step beyond the safeguards approach. During the last five years, the courts of at least ten states have ruled that hypnotically enhanced evidence will be inadmissible until it can be established that hypnosis in general is a reliable method of

104. See Note, supra n. 91 at 603.

105. Chapman v. The State of Wyoming 638 P. 2d 1280 (Wyoming 1982); State v. Armstrong Wisconsin No. 81-2336-CR (1983); State v. Beachum 97 N.M. 682, 643 P. 2d 246 (1981). Also see: People v. Lewis 103 Misc. 2d 881, 427 N.Y.S. 2d 177 (1980); People v. McDowell 103 Misc. 2d 831, 427 N.Y.S. 2d 181 (1980); State v. White 26 Crim. L. Rep. (BNA) 2168 (Wisc. Cir. Ct. 1979); United States v. Admas 581 F. 2d 193 (9th Cir. 1978); People v. Hughes 417 N.Y.S. 2d 643 (Cty Ct. 1980).

106. Id.

107. See discussion supra at section III(C) of text. 
enhancing memory. ${ }^{108}$ The first in this line of cases was State v. Mack. ${ }^{109}$ Mack, it will be recalled, was a case involving an alleged sexual assault with a knife. ${ }^{110}$ With the aid of hypnosis the complainant described the alleged assault and the accused. The Court ruled that, as hypnosis is a scientific technique, it must meet the test laid down in Frye v. United States "' before evidence generated by the technique would be admissible. Frye laid down the rule that before admissible evidence could flow from a scientific technique, there must be a general acceptance of the technique by the scientific community as valid and reliable. ${ }^{112}$

In applying the Frye test to hypnosis, the Court considered the testimony of several noted experts in the area. ${ }^{113}$ It concluded that there was no consensus among the appropriate scientific community that hypnosis was a reliable method of enhancing memory. In fact the dangers of confabulation and suggestibility inherent in hypnosis militated against such a consensus. Accordingly, the Court in Mack excluded the evidence.

It is important to note that the exclusion of evidence in Mack did not amount to rendering the witness incompetent to testify. As the Court stated, "a witness whose memory has been 'revived' under hypnosis ordinarily must not be permitted to testify in a criminal proceeding to matters which he or she 'remembered' under hypnosis." "14 Thus the witness is permitted to testify as to matters recalled and recorded prior to hypnosis.

It has been argued that Mack and the line of cases following it are based on a misapplication of the Frye principle. Frye itself involved a question of whether an early form of lie detector accurately discriminated between truth and lies. ${ }^{113}$ Therefore, one writer claims, it is inappropriate to apply this principle to a process that does not purport to determine truth but rather to enhance memory. ${ }^{116}$

This argument takes a rather narrow and mechanistic view of the Frye decision. While it is true that Mack and the cases that followed did not directly apply Frye, their analogy to the Frye principle was a correct one. The purpose of a lie detector is to elicit truth. If the scientific community

108. Arizona (State ex rel Collins v. Superior Court 132 Ariz. 180, 644 P. 2d 1266 (1982)); California (People v. Shirley 31 Cal. 3d 18, 641 P. 2d 775, 181 Cal. Rept. 243 (1982)); Indiana (Strong v. State - Ind. -, 935 N.E. 2d 969 (1982)); Maryland (Collins v. State 56 Md. App. 186, 447 A. 2d, 1272 (1982)); Massachusetts (Commonwealth v. Kater 388 Mass. 519, 447 N.E. 2d 1190 (1983)); Michigan (People v. Gonzales 108 Mich App. 145, 310 N.W. 2d 306 (1981)); Minnesota (State v. Mack 292 N.W. 2d. 764 (Minn. 1980)); Nebraska (State v. Palmer 210 Neb. 206, 313 N.W. 2d 648 (1981)); Pennsylvania (Commonwealth v. Nazarovitch 496 Pa. 97, 436 A. 2d 170 (1981)); Washington (State v. Martin 101 Wash. 2d 713, 684 P. $2 \mathrm{~d} 651(1984))$.

109. Id.

110. See discussion corresponding with notes 63,64 . This case is discussed in Bélanger, supra $n .34$ at 882.

111. 293 F. 1013 (D.C. Cir. 1923).

112. Id.

113. Dr. Carl Malmquist, Dr. Allan Roberts, Dr. Charles Mutter, Dr. Leo Alexander, and Dr. Martin Orne.

114. Mack, supra n. 108 at 768.

115. Frye, supra n. 111.

116. N.J. Cripper, "People v. Shirley: An Unwarranted Per Se Exclusion of Hypnotically Enhanced Testimony?" (1983-84) 14 S.W.U.L.R. 777 at 808. 
does not agree that a lie detector does this, then admission of lie detector evidence would be both prejudicial and of little probative value. Analogously, as the purpose of hypnosis is to enhance recall, and as the scientific community does not agree that it does this, it is not stretching the Frye principle very far to say that hypnotically enhanced evidence should be excluded.

\section{THE INCOMPETENCE APPROACH}

A final approach to the hypnotic enhancing of evidence is the rendering of a witness incompetent to testify after having undergone a hypnotic session. The foremost advocate of this position is Dr. Bernard Diamond who forcefully argues that: ${ }^{17}$

\footnotetext{
... once a potential witness has been hypnotized for the purpose of enhancing memory his recollections have been so contaminated that he is rendered effectively incompetent to testify. ... After hypnosis the subject cannot differentiate between a true recollection and a fantasy or suggested detail. Neither can any expert or trier of fact. The risk is so great, in my view, that the use of hypnosis by poice on a potential witness is tantamount to destruction or fabrication of evidence.
}

Recent case law has transformed Dr. Diamond's academic proposition into an active legal issue.

The critical case supporting the incompetence position is the California Supreme Court's decision in People v. Shirley. ${ }^{118}$ Here the Court applied the Frye principle, noting that the Court need not "decide whether hypnotically induced recall of witnesses is reliable as a matter of 'scientific fact', but simply whether it is generally accepted as reliable by the relevant scientific community." "19 Applying this test, the Court found that the scientific community did not view hypnosis as a reliable method of enhancing memory. ${ }^{120}$ On this basis the evidence was excluded.

It is the ambit of the exclusion, however, that makes Shirley more than an unremarkable application of Mack. The Shirley Court limits a witness's competence to testify to matters "wholly unrelated to the events that were the subject of the hypnotic session."'21 This ruling goes beyond the typical exclusion cases which would allow a witness to testify to facts "demonstrably recalled"122 prior to hypnosis.

The obvious practical difficulty arising out of the incompetence approach is that it forces law enforcement officials to choose between using a witness during the investigatory phase and using the witness at trial. Faced with this Hobson's choice, the police may well substantially curtail their use of pre-trial hypnosis, for fear of jeopardizing the prosecution's case. This prospect is particularly unappealing as given the hit and miss nature of hypnotic enhancing of memory, it is in the production of investigatory leads that its use is most appropriate.

117. Diamond, supra n. 17 at 314.

118. Supran. 108.

119. Id. at 55, 641 P. $2 d$ at 797, 181 Cal. Rptr. at 265.

120. Id. at 56,641 P. 2d at 797-98, 181 Cal. Rptr. at 266.

121. Id. at 67,641 P. 2d. at 805, $181 \mathrm{Cal}$ Rptr. at 273.

122. Cripper, supra n. 116 at 817. 
At least one other American jurisdiction has adopted the hard line incompetence rule, only to move back soon thereafter to the milder exclusionary rule. ${ }^{123}$ The latter position would seem preferable to the former. By allowing testimony concerning memories related and recorded prior to hypnosis, the courts obtain valuable evidence relatively untainted by suggestion and confabulation. At the same time the police are not precluded from using hypnosis for valuable investigatory purposes.

\section{THE CANADIAN CASE LAW}

In comparison to the rich and variegated American jurisprudence on the admissibility of hypnotically enhanced evidence in criminal proceedings, the Canadian position seems underdeveloped indeed. A thorough survey of the relevant literature and reported cases revealed only five cases on point. ${ }^{124}$ As there are so few decisions to date, it would be appropriate to examine each individually.

The first reported Canadian case considering the admissibility of hypnotically enhanced evidence was the British Columbia case of $R$. v. Pitt. ${ }^{125}$ Here Mrs. Pitt stood accused of the murder of her husband with a hammer. Her lawyer proposed to have her hypnotized in court to help her to recall what transpired. Aitkins J. ruled that while he would not allow testimony to be given while the accused was in a hypnotic trance, he would allow an in-court memory enhancement. ${ }^{126}$

The Court saw hypnotic enhancement of memory as analogous to surgery removing a clot on the brain that was interfering with recall. ${ }^{127}$ Since both of the expert witnesses were called by the defence, ${ }^{128}$ it is not surprising that the Court had such a one-sided view of the nature of hypnosis. It appears from the transcript that the problems of suggestibility and confabulation were not brought to the Court's attention. Further, although the Court was cognizant of the problem of undue weight, it permitted the highly dramatic process of hypnosis to be carried on before the jury. ${ }^{129}$ Clearly this case amounted to a very unbalanced first attempt at the thorny issue of hypnotic enhancement.

A second attempt to deal with this issue is found in the Manitoba Provincial Court case of $R$. v. $K .{ }^{130}$ Here the Crown sought to introduce hypnotically enhanced evidence, in order to support a charge of criminal negligence causing death, arising from a driving incident. The Court concluded that the evidence was inadmissible. ${ }^{131}$

123. See State v. Palmer, 210 Neb 206, 313 N.W. $2 d 648$ (1981) and the subsequent case of Statev. Patterson 213 Neb 686, - N.W. 2d - (1983).

124. Involuntary hypnosis cases such as $R$. v. Booher [1928] 4 D.L.R. 795. (Alta S.C.) and Horvath v. The Queen 44 C.C.C. (2d) 385 (S.C.C.) are beyond the scope of this paper.

125. [1968] 3 C.C.C. 342 (B.C.S.C.).

126. Id. at $343,346$.

127. Id. at 346.

128. Id. at 345 .

129. Id. at 348.

130. (1979) 47 C.C.C. (2d) 436 (Fam. Div.).

131. Id. at 449. 
This Court was clearly more attentive to the dangers inherent in hypnosis. Garfinkel Prov. Ct. J. states: $:^{132}$

Hypnotism is not infallible and there are difficulties in obtaining truth from a hypnotized subject. The subject can mingle fact with fantasy. There may be a subconscious desire on the part of the subject to co-operate with the hypnotist. ... The subject, under hypnosis, may lie or distort the actual events in his mind. The hypnotist ... could suggest a response or answer and easily affect the memory recall of the subject. This could come about intentionally or just by association.

Hypnosis, the Court concluded, is not a reliable method of enhancing recall.

It is not entirely clear from reading the case report, upon what legal basis the Court excluded the hypnotically enhanced evidence. The best interpretation, however, is that $R$. v. $K$. relies on the narrow exclusionary rule laid down by the Supreme Court in $R$. v. Wray.${ }^{133}$ Here the majority held that evidence in criminal proceedings could only be excluded when it is gravely prejudicial and of trifling probative value ${ }^{134}$ In finding that hypnotically enhanced memory could suffer from severe distortion and confabulation, it followed that its admission would have little probative value and would be prejudicial to the accused having a fair trial.

Perhaps the least adequate Canadian decision to date is the recent case of R. v. Zubot, ${ }^{135}$ coming out of the Alberta Court of Queen's Bench. Here the issue was the admissibility of testimony by a Crown witness who had seen a killing from her bathroom window. The witness had undergone pre-trial hypnosis to enhance her recall. In a rather short and sparsely reasoned judgment, Hetherington $\mathrm{J}$. (as she then was) found the evidence admissible. ${ }^{136}$

Given the discussion above of the frailties inherent in hypnosis, the shortcomings of this case are glaring. The following facts underline the problems with this decision:

1. The hypnosis session was not videotaped; ${ }^{137}$

2. The hypnotist was a sergeant in the Calgary Police Force. He was an experienced hypnotist but was neither a psychologist or psychiatrist; ${ }^{138}$

3. Only a partial written transcript of the hypnotic session was available; ${ }^{139}$

4. The limited transcript that was available revealed some leading questions; ${ }^{140}$ and

5. Police officers were present during the hypnotic session. ${ }^{141}$

The risk of distortion and confabulation was clearly great. The Court,

132. Id. at $447,448$.

133. (1970) 11 D.L.R. (3d) 673, [1970] 4 C.C.C. 1 (S.C.C.).

134. Id. C.C.C. at 17.

135. (1983) 47 A.R. 389 (Alta. Q.B.).

136. Id. at 393.

137. Id.

138. Id.

139. Id.

140. Id.

141. Id. 
however, presented with a poorly researched and developed defence argument, ${ }^{142}$ blithely accepted the admissibility/weight position.

In $R$. v. Clark, ${ }^{143}$ Canada's first reasonably well researched hypnotic enhancement case, the Alberta Court of Queen's Bench followed Zubot. While the Court recognized the dangers involved with hypnotic enhancement, it felt that it would be "an extraordinary case"14 that remedied these dangers with evidence exclusion. Further, the Court concluded, exclusion could not be justified on the $R$. v. Wray basis when, as in Clark, it was the accused who wished to introduce hypnotically refreshed testimony. A strict reading of $\boldsymbol{R}$. v. Wray only allows exclusion when the evidence is highly prejudicial to the accused. ${ }^{145}$

As an alternative to the exclusion approach, the Clark Court adopted the safeguard laid down in State v. Hurd, supplemented by a few guidelines of its own invention. ${ }^{146}$ These guidelines, the Court states, "are directed at minimizing the danger that a potential witness's testimony will be tainted by the intentional or inadvertent suggestion of information". ${ }^{147}$ As the Court had ruled out exclusion, it concluded that non-compliance with these guidelines would go to weight.

The most recent case in point is the $R$. v. Archer ${ }^{148}$ decision of the Supreme Court of Ontario, endorsed by the Ontario Court of Appeal. This case refused to allow the hypnotic enhancing of the memory of the accused. The decision was largely based on the fact that the counsel had waited too long before seeking permission to introduce the evidence. The Court was, however, "concerned about the accuracy of the information obtained through hypnosis and the propriety of a witness refreshing his memory in this way". 149

In the final analysis it would seem that Canadian case law is running about a decade and a half behind that of the United States. To date, Canadian approaches have been relatively unsophisticated. The rich American experience has been virtually ignored by both counsel and the courts. Unless Parliament intervenes it is likely that Canadian courts will stumble case by case along the same road the Americans have travelled.

\section{LEGISLATIVE REFORM}

The hypnotic enhancing of evidence is a prime candidate for legislative reform. At least one state has already laid down its rules in codified form. . $^{150}$ A section in the Criminal Code addressing this evidentiary issue could both lessen the potential dangers of hypnosis and create a uniform practice across Canada. Without such a section, Canada's courts will likely struggle

142. Id. at 391-393.

143. (1984) 13 C.C.C. (3d) 117 (Alta. Q.B.).

144. Id. at 123.

145. Id. at 124.

146. Id. at 125.

147. Id.

148. Unreported, 14 March 1984 (Ont. C.A.).

149. Berger, supra n. 36 at 75.

150. Oregon has done this. See McLaughlin, supra n. 44 at 690. 
with the issue for many years to come, just as the American courts have done.

\section{CONCLUSION}

Hypnotic enhancement of evidence, while offering great potential aid to the criminal justice system, is no panacea. Indeed, if simply admitted into evidence, absent any procedural safeguards, it will undoubtedly create substantial abuse. It is urged that Canada's law reformers examine this growing issue and adopt a compromise position between the naive admissibility approach on one hand and the overly extreme witness incompetence approach on the other. 